\title{
Analysis of the Quality of the River Kundur in the Review of the Physical-Chemical
}

\author{
Kiki Maini Hasibuan', Arman Harahap ${ }^{2}$ \\ ${ }^{1,2}$ Faculty of Teacher Training and Education, Universitas Labuhanbatu, Indonesia \\ armanhrp82@yahoo.co.id
}

\begin{abstract}
The purpose of this study is to analyze the water quality of the river and the status of water quality of watersheds Kundur Kabupaten Labuhanbatu. Sampling was done at 3 monitoring points along the flow of the river Kundur Kabupaten Labuhanbatu. The determination of the sampling points in the field using the purposive sampling method, with the determination of the sampling points based on the differences in the characteristics found in the study area.Some of the parameters measured were temperature, conductivity, COD, BOD, and oil/ fat are then compared with the criteria of the Raw water Quality of the river class II according to PP R. I. No. 82 Year 2001.On Water Quality Management.Based on the results of the analysis of the obtained results that in the area of monitoring point 1, is the most polluted areas.This is because, in this area there is the activity of a diverse community.Household produces waste that comes from the activity of the bathroom, toilet, kitchen, washing clothes and washing of household appliances.
\end{abstract}

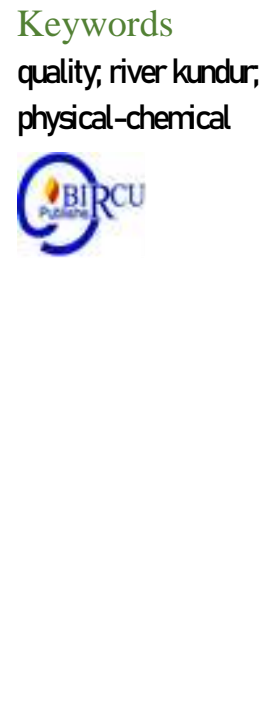

Keywords

quality, river kundur, physical-chemical

\section{Introduction}

The ecosystem of the water contained in the mainland (Inland Water) in general can be divided into 2, namely the waters of tapering (lenticular pocke Water) or also referred to as the calm waters, for example lakes, swamps, reservoirs, ponds, and so on and the waters lotik (Lotic Water) also referred to as the waters of the fast flowing, for example a river, times, canals, ditches and so on.The main difference between the waters of the lotik (lotic) and tapering (lenticular pocke) is in the speed of water flow. The waters of the tapering has current speed is slow as well as the accumulation of a mass of water that lasts with fast River Kundur including the waters of the tapering (Lotic Water) or also called calm waters (Barus, 2001).

The system waters cover the $70 \%$ part of the surface of the earth is divided in two main categories, namely freshwater ecosystems and aquatic ecosystems of the sea.From the second system the waters of the sea water has the most substantial part of more than $97 \%$, the rest is fresh water which is very important for human beings to the activity of his life (Barus, 1996).

River Kundur merupakansungai used by the society such as agriculture, Fisheries. The presence of a variety of human activities around the River such as the presence of Palm oil Mill which resulted in the River Aek Kundur is thought to be contaminated. Bentos as a marine bottom waters are relatively easy to migrate is a group of organisms that have suffered the most from the pollution of the waters. According to Odum (1994) explains that the biotic component can provide an overview of the physical condition, chemical and biological characteristics of waters. One of biota that can be used as a parameter of biology in determining the condition of the waters is the Macrozoobenthos. 
The components of the environment both living (biotic) or die (abiotic) influencing the abundance and diversity of biota that there is water on the waters, so that the high abundance of individuals of each type can be used to assess the quality of the waters. The waters are of good quality usually has the high species diversity and vice versa in the waters of a bad or contaminated (Fachrul, 2007).

The number of pollutants in the waters can give two influence on aquatic organisms, which can kill certain species and vice versa can support the development of other species. So when the water is polluted there is a possibility there is a shift from the number of species with population being the number of species of which little but the population is high.Therefore a decrease in species diversity can also be considered as a pollution.

\section{Research Methods}

\subsection{Preparation of Sampling}

This research was conducted in the flow of the River Kundur Phallus Three Kabupaten Labuhanbatu Sumatera Utara.that is when the River Aek Kundur in the state after the flood. Based on the zones of the environment that there is a set of 3 observation stations are different. River Kundur have been widely used by the population in the Village of Lingga Three activities, namely agriculture, Fisheries, and various household activities, which empties into the River Kundur. This study will be conducted in the month of Desemer 2020 until February 2021. sampling of macrozoobenthos was done by using Purposive Random Sampling technique to determine the 3 (three) observation stations. Sampling of macrozoobenthos done as much as 9 replications at each sampling station is performed at the point-point monitor has been determined. At any point of the monitor set 3 sampling points, i.e., edge 1, the middle, and the edge 2 with three repetitions in each of the three sampling points are different. Sampling was done during the day. Water quality sampling was conducted with a sampling tools simple dipped approximately 1 meter from the surface of the waters.

\subsection{Tools and Materials}

The tool used at the time of sampling, among others, is a set of tools for the sampling of water, polyethylene bottles, ice box, meters, DO meters, and to the Laboratory.

\subsection{Sampling Method}

Monitoring point sampling is determined along the watershed Kundur. Water sampling was conducted in 3 sub-station that is part of the middle and at both edges using a sample bottle with a volume of about $250 \mathrm{ml}$. Sampling was done with a method that has been done by Irham et al., (2017), which by the way, sample bottles back the rate of flow of water and instantly closed in the water. Treatment is done so that at the time of water sampling, the sample is not contaminated by the interference caused by the movement of currents that cause the occurrence of air bubbles that affect the quality of the sample taken. Water samples inserted in polyethylene bottles, preserved with $\mathrm{H}_{2} \mathrm{SO}_{4}$ concentrated as much as $0.3 \mathrm{ml}$. for further given a label (covering the monitoring point, the plot, date, time, and temperature), and then stored in the ice box that contains the fractional ice cubes and closed the meeting. 


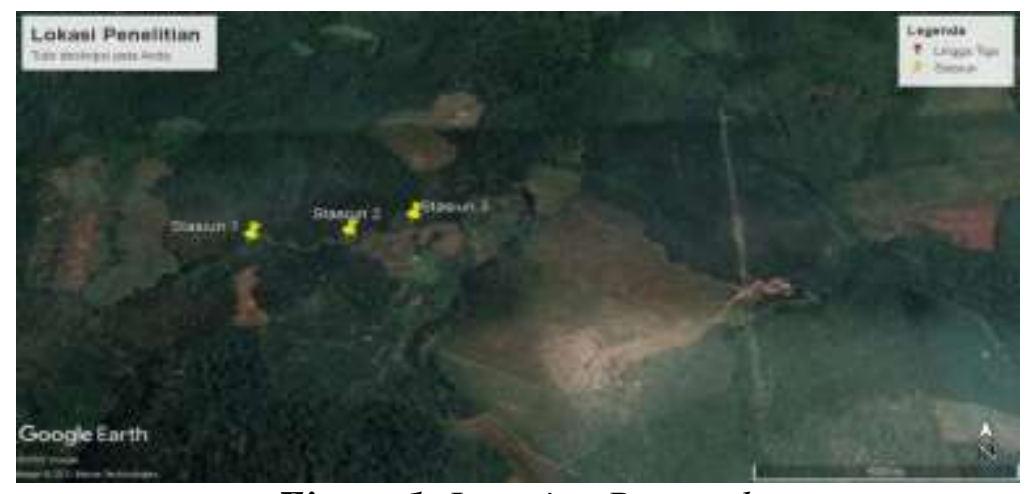

Figure 1. Location Research

The water temperature at the time of the measurement is measured by using a thermometer that is inserted into the sample for approximately 5 minutes. Furthermore, the results read the scale of the thermometer recorded with units of ${ }^{\circ} \mathrm{C}$.For the data of conductivity, measured using konduktivitimeter in situ by immersing the head of the conductivity in the sample. Shake the probe to remove air bubbles from the internal examination. The measurement is completed, if the reading of the results on the screen has stabilized. Each testing sample, the tools used must be calibrated to maintain accuracy of measurement.

Table 1. The Parameters of the Waters of the Water Quality and Testing Methods Used No Parameters Unit Instrumentation Analysis

\begin{tabular}{lllll}
\hline 1 & Temperature & ${ }^{\circ} \mathrm{C}$ & Thermometer & Laboratory \\
2 & Conductivity & $\mu \mathrm{mhos} / \mathrm{cm}$ & Laboratory & Laboratory \\
3 & DO & $\mathrm{mg} / \mathrm{l}$ & DO Meter & Laboratory \\
4 & BOD & $\mathrm{mg} / \mathrm{l}$ & Winkler Method & Laboratory \\
5 & COD & $\mathrm{mg} / \mathrm{l}$ & Reflux Method & Laboratory \\
6 & Oil / Fat & $\mathrm{mg} / \mathrm{l}$ & Gravimetri Method & Laboratory \\
\hline
\end{tabular}

\section{Results and Discussion}

The allotment of the river Kundur can be used for the cultivation of freshwater fish, livestock, irrigating crops, and / or other uses that require the quality of water is equal to the usefulness of such. The results of measurements of water quality with physical chemical parameters at each monitoring point, compared with the Criteria of Quality of the Raw river water PP R.I. No. 82 Year 2001 On Water Quality Management.

Change the temperature effect on the process physics, chemistry, and biology of the water body. Temperature is one of the external factors that are most easy to be researched and determined. The higher the water temperature, the greater the solubility of the oxygen in the water. Any increase in temperature of $10{ }^{\circ} \mathrm{C}$, it will accelerate the rate of chemical reaction by 2 times. For example the example of the reaction of the balance of ammonia $\left(\mathrm{NH}_{3}\right)$, will be shifted to the right and cause ammonia levels to increase. So the toxicity of ammonia will also increase. 
Table 2. The Results of the Analysis of Water Quality River Kundur in Kabupaten

Labuhan Batu against Each of the Parameters

The Results of the Analysis of the Criteria

Monitoring Point to the Parameters Water

Parameters Unit

$\begin{array}{lllllll} & & & & & \text { Quality } \\ 1 & 2 & 3 & 4 & 5 & 6 & \text { Class III }\end{array}$

Method

\begin{tabular}{|c|c|c|c|c|c|c|c|c|c|}
\hline Temperature & ${ }^{\circ} \mathrm{C}$ & 29 & 32 & 34 & 31.5 & 30 & 28 & \multicolumn{2}{|c|}{ deviation $3^{\circ} \mathrm{C} \mathrm{DO}$ meter } \\
\hline Conductivity & $\mu \mathrm{mhos} / \mathrm{cm}$ & 531 & 540 & 524 & 538 & 502 & 426 & $<600$ & Conductivity meter \\
\hline DO & $\mathrm{mg} / \mathrm{l}$ & 13.9 & 12.7 & 8.6 & 15.4 & 11.9 & 16.4 & 3 & DO meter \\
\hline BOD & $\mathrm{mg} / \mathrm{l}$ & 23.6 & 17.5 & 32.8 & 12.8 & 14 & 15.5 & 5 & $\begin{array}{l}\text { SNI 06-69899.72- } \\
2009\end{array}$ \\
\hline & & & & & & & & & $\begin{array}{l}\text { APHA, } 5220 \text { D } \\
\text { Coloricmeter }\end{array}$ \\
\hline COD & $\mathrm{mg} / \mathrm{l}$ & 146 & 19.1 & 12.8 & 54.4 & 49.1 & 32.3 & 45 & $\begin{array}{l}\text { Method, 21th ed, } \\
2012\end{array}$ \\
\hline Oil \& & & & & & & & & & IK. No. \\
\hline Fat & $\mathrm{mg} / \mathrm{l}$ & 2.5 & $<0.2$ & $<0.1$ & $<0.1$ & $<0.2$ & $<0.1$ & 1 & 33/MU/01.31/LP \\
\hline
\end{tabular}

The results of the analysis of measurements at the monitoring point in situ, temperature conditions in the watershed Kundur in Phallus Three, did not change with high intensity. Temperature range there is at a temperature of $28-34{ }^{\circ} \mathrm{C}$. The difference in the value of the temperature at the top is because, the density of residential population and the condition of the river that is open so that more sunlight is exposed on the surface of the water of the river. But it is also the silting of water bodies.

Conductivity is a picture of the numerical representation of the ability of water to continue the flow of electricity. Therefore, the more salt-dissolved salt that can be ionized, the higher conductivity values. Whereas if the value of the conductivity is higher, then the bad water quality (Arlindia \& Afdal, 2015). Based on table 2 above, the average value of conductivity in the River Kundur Phallus Three, ranged from 400 to $500 \mu \mathrm{mhos} / \mathrm{cm}$. This value is still relatively good and still qualify quality standards set by the FAO for agriculture amounted to $<600 \mu \mathrm{mhos} / \mathrm{cm}$. The value of the conductivity of the waters will affect the quality of the water.

The value of the DO-Dissolved Oxygen, the results of the analysis at all monitoring points has exceeded the water quality standard class II based on No. 2 of 2008 and PP R.I No. 82 Year 2001. Dissolved oxygen (DO)is the amount of oxygen contained in the water and is measured in units of $\mathrm{mg} / \mathrm{l}$. Dissolved oxygen is used as a sign of the degree of doping of the waste that exists. Dissolved oxygen needed by all the bodies of living for respiratory, metabolic processes or the exchange of substances which then produce energy for the growth and breeding. In addition, oxygen is also needed for the oxidation of organic materials and inorganic materials in the process of aerobics. Generally oxygen found in the surface layer due to oxygen from the air in nearby can directly dissolve diffuses into the water of the river (Hamuna et al., 2018). The content of dissolved Oxygen associated with the level of pollution, types of waste, and the amount of material organikdi a region of the waters. 
The results of the test analysis DO watershed Kundur Phallus Three shows a tendency, that with the high value of COD then the levels of BOD and COD will tend to fall. This is in accordance with the explanation Irham et al., (2017) which states if the dissolved oxygen content is low, then the waste material of organic in water is high, and vice versa. According to Yudo (2010), that the greater the concentration of BOD of the waters, then it will be an indicator of the high concentration of organic material in the water. BOD or Biochemical Oxygen Demand is a characteristic that shows the amount of dissolved oxygen that required by microorganisms to break down or mendekomposisikan organic matter under aerobic conditions. The value of BOD is used as the index to measure pollutants from waste that are in the waters.

Parameter BOD is the parameter most widely used to determine the level of water pollution. The higher the concentration of BOD, indicating that these waters have been polluted. The results of the test analysis of the BOD watershed Kundur Phallus Three, ranged from 13 - to $15.4 \mathrm{mg} / 1$. The highest value contained in the monitoring point 1 and point monitor 2. This condition is influenced by the location of the river near residential areas, shopping centers, traditional markets, and the number of stalls at the edge of the river. Activities of about the location of the monitoring points this is a source of organic material derived from the remnants of food or food ingredients. Based on the report Wibowo et al., (2014) that the area of urban close to the city market produce waste organic material that is relatively high.

Chemical Oxygen demand (COD) indicates the total amount of oxygen required to oxidize the organic material in kimiawiataupun that can be biologically degraded (nonbiodegradable) into $\mathrm{H}_{2} \mathrm{O}$ and $\mathrm{CO}_{2}$.

\section{$\mathrm{C} 6 \mathrm{H} 12 \mathrm{O} 6+6 \mathrm{O} 2 \rightarrow 6 \mathrm{H} 2 \mathrm{O}+6 \mathrm{CO} 2$}

The value of COD is directly proportional to the value of BOD and inversely proportional to the DO, which means the higher the value of COD then the value of BOD is also high, but the value of the DO will be low. The difference in the value of BOD and COD is an idea of how much organic material that is difficult to decompose in the waters. The value of COD that exceeds the quality standard shows that the waters of the proficiency level has been contaminated organic material. It is also supported by the results of the research Supriyantini et al., (2017) in his research that discusses the concentration of organic matter in the waters of the mangrove, that the value of the COD and the BOD value each other directly proportional. As for the value of COD against both parameters are inversely proportional.

Quality of the raw values of COD are suggested for agriculture and fisheries amounted to $45 \mathrm{mg} / 1$. However, based on the results of the analysis in the monitoring point 1 , it produces the value of the concentration of $146 \mathrm{mg} / \mathrm{L}$. This condition shows that the area of the flow of the river has been polluted by the impurity with a concentration value are high. This leads to the decomposition process in the biological is not enough to reduce the burden of the volume of waste that goes into a body of water. So the process of the decomposition of the chemical must be applied to break down and decompose pollutant loads into the flow of the river water. The high value of COD in the monitoring point 1 is aligned with the high value of BOD in the same location, indicating that the load of waste that goes into the flow of the river has been mixed.

Based on table 2 the results of the above analysis, the increase in BOD and COD which is followed by the high levels of oil/ fat there is on the station. This is because, in this area there is the activity of a diverse city. households produce waste comes from the bathroom, toilet, kitchen, washing clothes and washing of household appliances. Qualitatively household waste consisting of organic substances either solid or liquid, sea 
salt, oils and fats and bacteria (especially bacteria E. Coli). The presence of a layer of oil on the surface of the water causes the penetration of the sun's light and oxygen in the water is reduced and resulted in the microorganisms decomposers difficult to day.

\section{Conclusion}

The water quality of the watershed is further based on the examination of parameters, including temperature, conductivity, BOD, COD, and oil / fat show result that does not exceed the quality standard. Human activity in the vicinity not to give an impact that can increase the contamination of the river kundur such.

\section{References}

Arlindia, I., and Afdal.2015. Analisis Pencemaran Danau Maninjau dari Nilai TDS dan Konduktivitas Listrik.Jurnal Fisika Unand Vol. 4 (4); 325-331.

Barus, T. A , 1996, Metode Ekologi untuk Menilai Kualitas Suatu Perairan Lotik. Program Studi Biologi USU FMIPA - USU, Medan.

Fachrul, M. F. 2007. Metode Sampling Bioekologi.Bumi Aksara. Jakarta.

Hamuna, B., Tanjung, R., Suwito, Maury, H. K., dan Alianto. 2018. Kualitas Air Laut dan Indeks Pencemaran Berdasarkan Parameter Fisika-Kimia Di Perairan Distrik Depapre,Jayapura. Jurnal Ilmu Lingkungan Vol 16 (1); 35-43.

Odum, E. P. 1994. Dasar-dasar Ekologi. Edisi Ketiga. Universitas Gadjah Mada Press, Yogyakarta (Penerjemah Tjahjono Samingar).

Supriyantini, E., Soenardjo, N., dan Nurtania, S. A. 2017. Kosentrasi Bahan Organik Pada Perairan Mangrove di Pusat Informasi Mangrove (PIM), Kecamatan Pekalongan Utara, Kota Pekalongan. Buletin Oseanografi Marina Vol 6 (1); 1-8.

Velasco, J., Dobarganes, C., and Ruiz, G. M. 2010.Chemical Deterioration and Physical Instabilityof Food and Beverages.Cambridge. Woodhead Publishing Limited.

Vol. 7; 1-7. Irham, M., Abrar, F., dan V, K. 2017. Analisis BOD dan COD di Perairan Estuaria Sungai Krueng Cut, Banda. Jurnal Ilmu-Ilmu Perairan, Pesisir dan Perikanan Vol. 6 (3); 199-204.

Wibowo, H. P., Purnomo, T., dan R, A. 2014.Kualitas Perairan Bengawan Solo di Wilayah Kabupaten Bojonegoro Berdasarkan Indeks Keanekaragamaan Plankton.Jurnal LenteraBio Volume 3 (3); 209-215.

Yudo, S. 2010. Kondisi Kualitas Air Sungai Ciliwung di Wilayah DKI Jakarta Ditinjau dari Parameter Organik, Amonia, Fosfat, Deterjen, dan Bakteri Coli.Jurnal Akuakuktur Indonesia Vol 6 